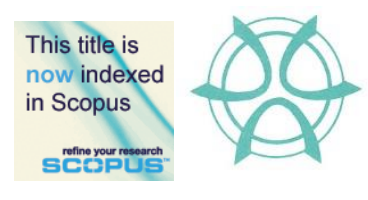

PLANNING MALAYSIA:

Journal of the Malaysian Institute of Planners

VOLUME 15 VOLUME 1 (2017), 377 - 388

\title{
LOCAL LEADERSHIP MODEL TOWARDS A RESILIENT CITY IN SEMARANG MUNICIPALITY
}

\author{
Lilin Budiati ${ }^{1}$ \\ ${ }^{l}$ EDUCATION AND TRAINING AGENCY OF CENTRAL JAVA
}

\begin{abstract}
This study assessed local leadership necessary for developing city resilience in the phase of more escalating, complicated and critical disaster phenomenon. The study departed from an assumption of the need for an effective and creative model of local leadership in order to transform risks into resilience, so that the city possesses a local capacity to develop Semarang as the resilient city. Leadership competency can be taught and trained by a leadership education and training under the Center for Education and Training of the Provincial Government of Central Java. Learning premise and practice of the leadership education and training in this study was formulated as follows: (1) Why was the leadership of Semarang Mayor unable to improve effectiveness of state internal bureaucracy towards city resilience?; (2) How was the model of local leadership necessary to develop Semarang city resilience?; and (3) What learning model of leadership education and training was effective to educate and to train the effective and creative bureaucratic leaders? Using a case study based qualitative approach, this study resulted in as the followings: (1) the mayoral leadership concerning hazard and city resilience issues was proven effective, but was unable to improve the effectiveness of the state internal bureaucracy due to structural conflict; (2) local leadership model related to disaster and city resilience issues that can be applied to Semarang Municipality is a congruent model with public-private partnership approach; and (3) the effective learning model that can be applied to the leadership education and training is a constructivist learning model with an intuitive approach.
\end{abstract}

Keyword: Local leadership, city resilience, constructivistic, leadership training and education

Date Received: $30^{\text {th }}$ April 2016

Date of Acceptance: $30^{\text {th }}$ October 2016 
Lilin Budiati

Local Leadership Model Towards a Resilient City in Semarang Municipality

\section{INTRODUCTION}

Semarang Municipality is a city familiar with disasters due to its geographical condition. The city is unique and specific, composed of coastal area at the "lower city zone" and highland at the "upper city zone". The coastal area is prone to such disasters as elevation of sea level, tidal flood, abrasion, and erosion, to mention some. Whereas, the highland has been identical with landslide, land movement, hurricane, drought, and flood due to high rainfall.

Previous studies (2009-2011) have proven that prior to 2010, effort from the municipal government of Semarang to overcome the disastrous conditions were technical, short-termed, and not integrated within medium- and long-term city planning. A study by Bisrie, Salim and Suroso (2011) revealed that Semarang became the coastal city in Indonesia with the most vulnerable of disaster. The Resilient City 2015 workshop identified shocks and pressures faced by Semarang. The determination of priority was done according to the 100RC tools by considering risk levels and probabilities. The workshop identified six major shocks currently faced by Semarang (Table 1):

Table 1 Disaster-Related Conditions in Semarang Municipality and Their Impacts

\begin{tabular}{|c|c|c|c|}
\hline No. & Shock & Major sub-mover & Main dimension \\
\hline 1. & Heavy flood & Ecosystem and asset management & Leadership and strategy \\
\hline 2. & Fire & Ecosystem and asset management & $\begin{array}{l}\text { Environment and } \\
\text { infrastructure }\end{array}$ \\
\hline 3. & Landslide & Ecosystem and asset management & Leadership and strategy \\
\hline 4. & $\begin{array}{l}\text { Dengue hemorrhagic } \\
\text { fever (DBD) }\end{array}$ & $\begin{array}{l}\text { capacity and facility of public } \\
\text { health service }\end{array}$ & Health and social welfare \\
\hline 5. & Drought & Ecosystem and asset management & $\begin{array}{l}\text { Environment and } \\
\text { infrastructure }\end{array}$ \\
\hline 6. & $\begin{array}{l}\text { Stability of raw } \\
\text { material supplies }\end{array}$ & $\begin{array}{l}\text { Provision, storage, and } \\
\text { distribution }\end{array}$ & Economy and social \\
\hline
\end{tabular}

Strategies and actions promulgated within the City Resilience Strategy had been performed under the co-ordination of the Working Group for the Resilience of Climate Change of Semarang Municipality, an ad hoc and multi-stakeholder team formalized by the Mayoral Decree of Semarang Municipality. The success of managing risk, adapting and mitigating disasters in a sustainable manner is affected by leadership, in particular the municipal leader (the mayor) and his or her municipal bureaucratic staff. Etzioni and Gross (1985) explain that a leader can be divided into two categories: formal and informal. Informal leaders are individuals with ability to control the others/followers by attribute, characteristic, and leadership capital derived from his or her personal strength. On the other hand, informal leaders are those having power due to his or her position, which, in turn, becomes the leadership requirement to influence the others, differing his or her from the "non leaders". 
Leadership is an art/way and/or ability to influence the others, to direct attitudes of subordinates or groups, to have particular abilities or proficiencies as required for obtaining organizational or group objectives (Kartono, 2003). Leaderships refers to three important aspects namely (1) leading process, (2) all leading activities or behaviours, and (3) ability to influence the others to perform particular duties determined by the leader for the group or organization objectives (Williams \& Cudjoe-Braithwaite, 2012).

In case of the current study, local leader is defined as a formal leader's leadership due to his or her strategic role and function in determining city (urban) development. By positional authority, formal leader is capable of mobilizing participation and collaboration of informal leaders and civil society to mutually develop local capacity for developing the city resilience.

The focal point of the local leadership comprises three leadership aspects namely (1) political leadership by the municipal leader (the mayor) and his or her bureaucratic leadership and staff, (2) professional and/or managerial leadership by professionals and/or higher education institutions, and (3) community leadership by community/civil society, non-government organization, autonomous institution and private sector leaders. Figure 1 illustrates the perspective of local leadership.

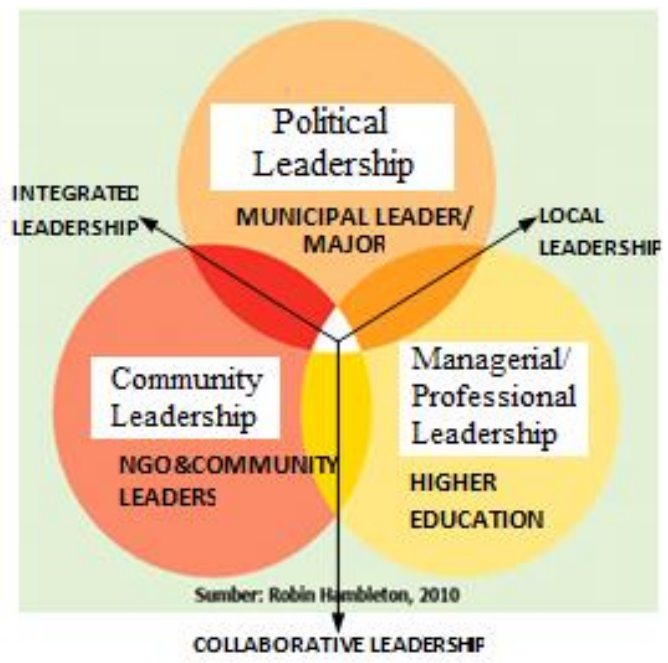

Figure 1 Local Leadership Perspective

Local leadership has an important role to develop local capacity to build a city resilience in order to decrease and to manage risk, to adapt, to give response, and to mitigate impact as well as to restore from damage and/or loss due to disasters. Towards this end, the local leadership is urged to integrate efforts of decreasing and managing the risk and adaptation of the disasters by planning the spatial development at short-, medium-, and long-terms. 
Lilin Budiati

Local Leadership Model Towards a Resilient City in Semarang Municipality

The purpose of developing the city resilience can only by achieved when the city is considered as a system where good urban governance is found.

The substantive meaning of the good urban development from the perspectives of disaster and city resilience are as follows: (a) the municipal government of Semarang becomes a conceptor, initiator, and implementor of policies on the local capacity building towards the development of a "resilient city" based on local identity, directing towards the actualizing "local identity", a situation that identifies localities of the city (geography, history, characteristics, and culture). These aspects become the foundation of the local capacity building; (b) local capacity building is achieved by productivity and growth in political, economic, social, and cultural aspects; (c) development efforts must allow participation of stakeholders and/or civil society at the stages of decision-making, planning, implementation, and evaluation; (d) development results, in forms of productivity and growth, must not be achieved by ignoring principles of equality and harmony in economic, social, and environmental aspects; and (e) urban system development must agree with the principles of good urban governance.

\section{RESEARCH METHODOLOGY}

This study applied a qualitative research method with a case study approach. The author assessed data with a comparative analysis, in a reflective manner, and followed it up with comparing interpretation translated into codes and categories.

\section{Research Design}

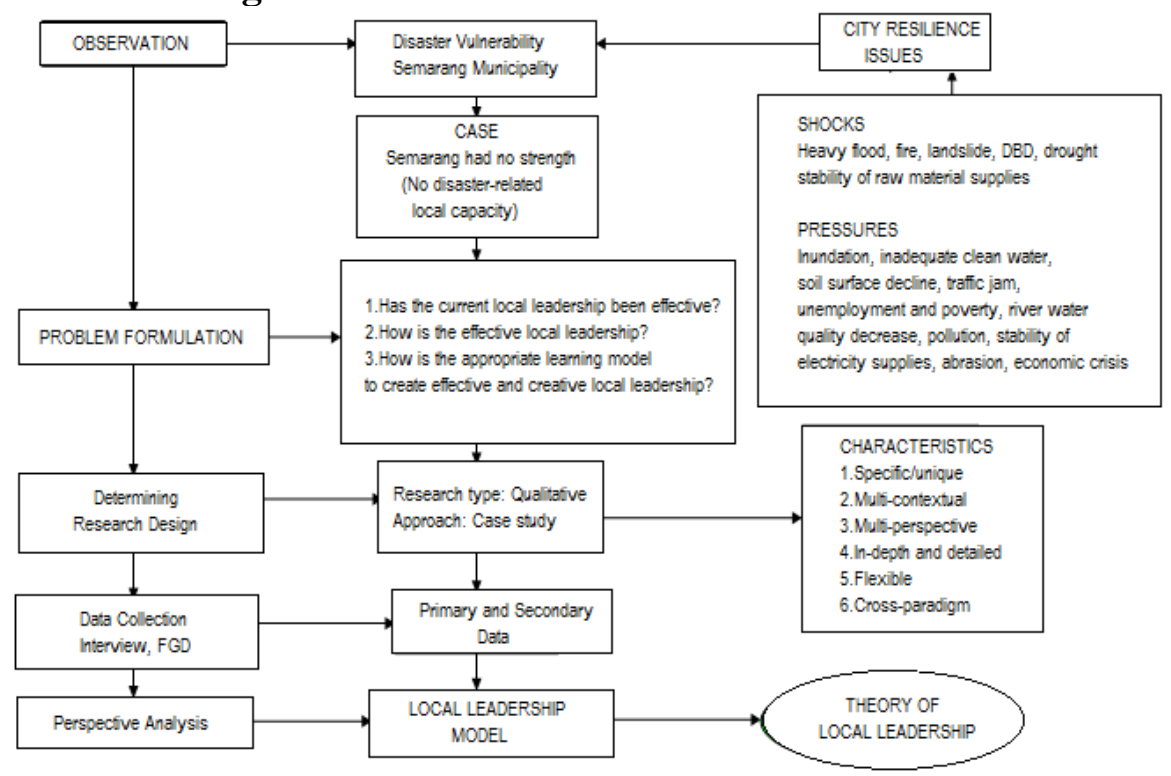

Figure 2 Research Design

Source: Remenyi et. al. (1998); CIPG elaboration by Budiati (2015) 
PLANNING MALAYSIA:

Journal of the Malaysia Institute of Planners (2017)

\section{Conceptual Framework}

A conceptual framework is a result of the author's thought about problems currently assessed and discovered to get the problem solution. It is a dialectical accumulation of vary activities, i.e. observation, seminar, workshop, and focus group discussion (FGD) concerning shocks and pressures faced by the city of Semarang due to hydro-meteorological and climate change disasters. The empirical reality observed was ecological damage footprints and vulnerability of the city towards the disastrous conditions, which had demanded the need for developing a sustainable, resilient city. Figure 3 illustrate the research conceptual framework.

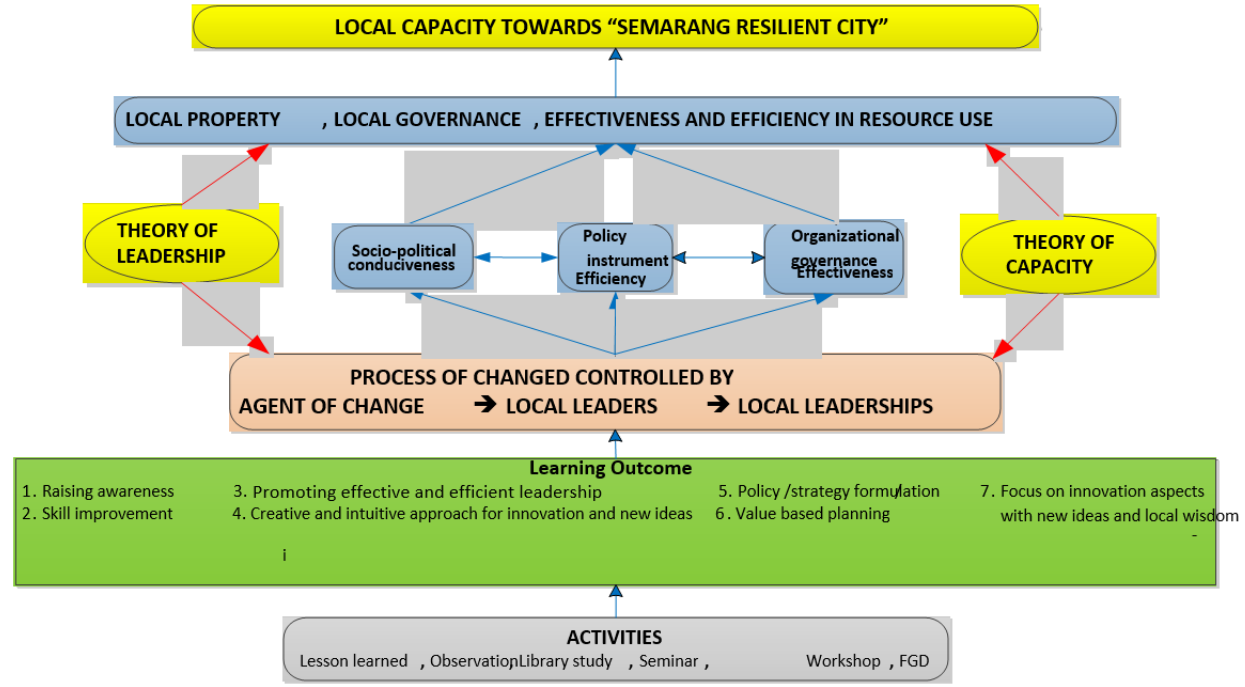

Figure 3 Conceptual Framework

\section{RESULTS AND DISCUSSION}

According to the Working Group for the Capacity of the Semarang Municipal RC Team (Municipal Government of Semarang, 2016), at sectoral level from the perspectives of disaster and city resilience, the effectiveness of the Semarang Mayor concerning the disaster (chronic shocks and pressures) had been in line with the reality, as the followings:

a) Evaluation and control of risk and adaptation to climate change impact

b) Financial and program aids from central government, international donors, and partner countries

c) Adaption and mitigation of acute shocks and chronic pressures (construction of folder, retention pond, critical area conservation, river stream restoration/west riverbank)

d) Development of strategy and roadmap for city resilience

e) Initiative of Semarang RC program 
Lilin Budiati

Local Leadership Model Towards a Resilient City in Semarang Municipality

\section{f) Establishment of Semarang Municipal RC Team}

At the larger scope, the FGD results proved that the leadership of the Semarang Mayor had not been effective to build the local capacity necessary for developing the city resilience, as proven by the following empirical facts:

a) Citizens of Semarang and the Performing Work Unit (SKPD) had not known and understood city resilience and/or Semarang RC programs

b) The implementation of the retention pond construction in Muktiharjo for overcoming flood and social aid project for poverty alleviation had not been accountable and been prone to corruption;

c) Programs/projects dealing with disaster control by the Municipal Disaster Prevention Agency (BPBD) and other concerned SKPDs were not integrated in a single package;

d) Lacking data and information of disasters. The available data were only understood by their makers.

e) "Alert Village" Program (Program Desa Siaga) promoted by the BPBD to build the preparedness and response of the community to the disasters was perceived as a subsidiary or grant project. Therefore, the BPBD was required to allocate funds by the community.

In case of BPBD of Semarang Municipality, the performance ineffectiveness is not merely caused by the poor influence and ability of the mayor to motivate BPBD to perform its principal duty and function effectively, but also due to internal gap because BPBD itself also lacks of instrumental efficiency by its structural construction. The BPBD structure is built upon Perka BNPB 3/2008 on the establishment of BPBD and Permendagri 46/2008 on Guide for Organization and Work of BPBD.

The FGD held on March 31, 2016 found that the ineffectiveness of the mayoral leadership for building the local capacity for developing a resilient city was due to the following factors:

a) The government tended to focus on policy or program during and post disaster. the policy only had a single purpose with a limited scope in particular disaster, such as flood. The implementation of the policy on flood in Semarang were as follows: early warning system, river sedimentation removal, road raising, and retention pond construction.

b) From the perspective of a city as a system and disaster context, the policy and program implemented by the municipal government of Semarang had not been effective because of lacking the good local/urban governance with the following principles: inclusion, productivity, locality, and sustainability. The program/project dealing with the flood was initiated by the government using the local budget (APBD) and/or the national budget (APBN) and had a single purpose to overcome problems related only to the flood. 
c) Social transformation where the citizens mobilize vertically and take part into the city planning did not occur. The mayoral policy flow was to-down and the aspiration and opinion flow of the citizens was bottom-up. Both flows were not integrated into a compromising point by mutual consent to make a decision of the city planning.

d) Gap between the effective mayor performance and ineffective local stage bureaucratic performance can be explained by the theory of situational leadership. According to Hersey and Blanchard (1998), the maturity of the subordinates (bureaucratic leadership under the mayor) is at the lowest level (unable and unwilling) to follow up and implement the Semarang RC program.

e) The position of the mayor as a political leader at the top of the hierarchy of the state bureaucratic structure at the local level, which manages the structural officials from the echelons IV to II, were generally career positions. This situation might lead to structural gap from authority distribution of the functions in the bureaucratic structure.

f) The establishment of the Semarang Municipal RC Team was ad hoc in characteristic. In other words, it was outside the bureaucratic structure. Thus, the Semarang RC program was unknown and lacking objective realities as the mutual agenda and goal.

Table 2 Ineffectiveness of Policy of Semarang Mayor

\begin{tabular}{cll}
\hline No. & $\begin{array}{c}\text { Cause of } \\
\text { ineffectiveness }\end{array}$ & \multicolumn{1}{c}{ Current condition of Semarang Municipality } \\
\hline 1 & $\begin{array}{l}\text { Practical politics } \\
\text { in planning }\end{array}$ & $\begin{array}{l}\text { Some policies of the Semarang Municipality were incremental, } \\
\text { incomprehensive, lacking preventive efforts. The government } \\
\text { tended to focus on policies or programs during or post disaster. The } \\
\text { comprehensive policy may result in good result or effect because of } \\
\text { rational thinking process supported by complete data or information. } \\
\text { It is expected to guarantee the sustainability of the policy. }\end{array}$ \\
\hline 2 & $\begin{array}{l}\text { Limited data and } \\
\text { information }\end{array}$ & $\begin{array}{l}\text { From the aspect of policy transparency, the government was not } \\
\text { active in socializing the policies on the city resilience the citizens } \\
\text { should have managed to access the information from either } \\
\text { conventional media or social media. For example, the policy on } \\
\text { license and surveillance of ABT in Semarang was relatively unclear. }\end{array}$ \\
\hline 3 & $\begin{array}{l}\text { Ego sector } \\
\text { Confusing programs caused multi-interpretative programs with } \\
\text { similar substances. }\end{array}$ \\
\hline $\begin{array}{l}\text { Programs/ } \\
\text { activities were } \\
\text { not aspiring, } \\
\text { participative, and } \\
\text { inclusive. }\end{array}$ & $\begin{array}{l}\text { A program or policy must be inclusive by involving and providing } \\
\text { opportunities to all stakeholders to give their opinions, complaints, } \\
\text { and to determine the role and contribution towards end result. } \\
\text { Implementation in Semarang Municipality still needed an } \\
\text { improvement of the citizens' active participation. } \\
\text { Private sector was expected to enlarge its role by co-ordinating with } \\
\text { the government and the community/civil society with an integrated } \\
\text { effort towards a much better policy implementation. }\end{array}$ \\
\hline
\end{tabular}


Lilin Budiati

Local Leadership Model Towards a Resilient City in Semarang Municipality

5 Poor monitoring The importance of monitoring and evaluation of the implementation and evaluation of a policy or program as the main indicator for finding out to which extent the program has been achieved, along with its obstacles and the solutions. The poor monitoring and evaluation became an obstacle for the Municipal Government of Semarang to implement its policies, such as that of dealing with Underground Water (ABT) license. The license had been strict by a prohibition at the red zone, but the monitoring and evaluation in practice must be actually performed to prevent violations.

6 Capacity of ad Institutional networks were not integrated in the planning process, as hoc institution evidenced by authority and program overlapping, causing the lacking focus of the program. A grand design should have been made available and mutually agreed by concerned parties, i.e. the government (Bappeda, BPBD, and concerned institutions), private, and community.

The Semarang Municipal RC Team had managed to develop an organizational structure, which composes of three local leadership, i.e. political leadership (the mayor), professional leadership (academics/higher education), and community leadership (civil society), as well as private sector, as illustrated by Figure 4.

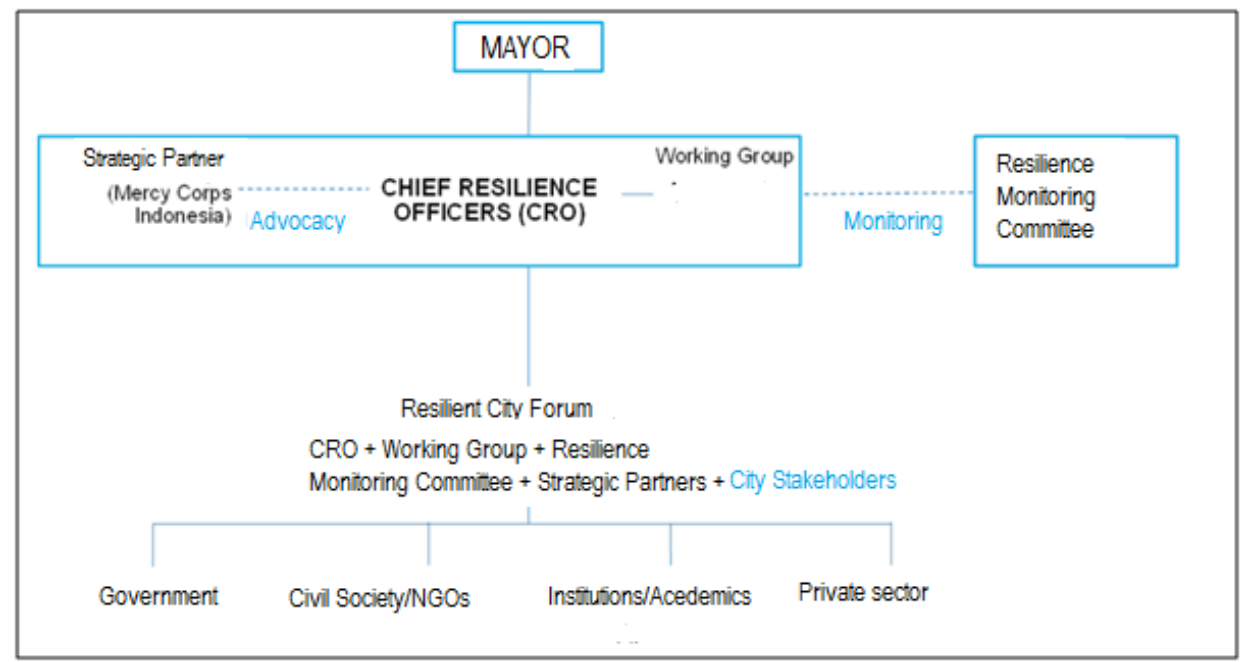

Figure 4 Organizational Structure of Semarang RC

The above organizational structure represents a policy networks at the program level with a public-private partnership. The problem will be how to make the program performance effective towards an optimal outcome. The main function of the local leadership, in particular the mayor, becomes a key factor to the successful program. However, the empirical reality proved the otherwise. 
Handayani (2015) found that the support of the municipal government of Semarang to the implementation of the $100 \mathrm{RC}$ program was not significant and "business as usual", without any innovation.

The involvement of the stakeholders through development plan meeting (Musrenbang) was ineffective and exposed by challenges. The developmental pattern tended to elitist, technical, partial and project oriented with short-term paradigm. In such condition, the local leader as the "agent of change" is necessary.

The $100 \mathrm{RC}$ contains formal (the government) and informal (nongovernment and civil society) organizational components. Therefore, a leadership model that integrates both component area needed. The formal organization of Semarang Municipal Government was structural (the functions were composed systematically in a hierarchical structure). Whereas informal organizations were functional (non-hierarchical structure). The difference in the organizational characteristics had created gap prone to counter-productive conflicts. The delineation of both components can be done by adopting a congruent model introduced by Nadler and Tushman (1997) modified by the program need.

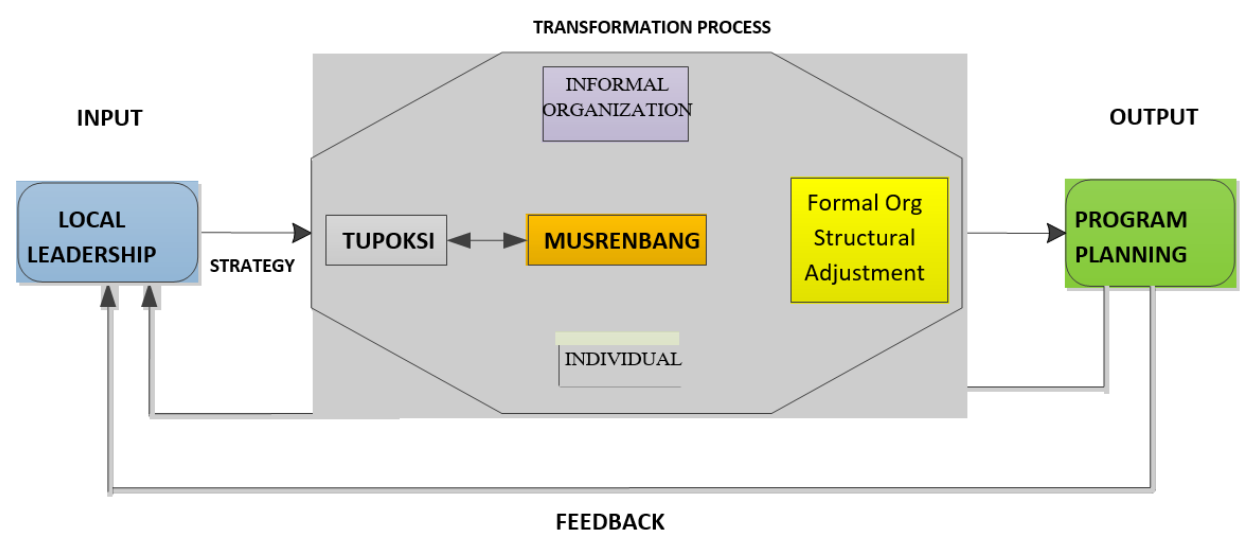

Figure 5 Local Leadership Model

At the input stage, there were components of local leadership, i.e. political leadership the mayor), professional leadership (professional organizations and higher education), and community leadership (civil society and NGOs). At the transformation stage, the strategy was transformed by the SKPD's principal duty and function as planned. At the output stage, work/program plans were established by a full support from the communities. The program/work plan implementation was monitored and evaluated in concert as feedback to the local leadership.

New pattern of Leadership Education and Training is a learning model based on experience by the State Administrative Agency (LAN) to replace the 
Lilin Budiati

Local Leadership Model Towards a Resilient City in Semarang Municipality

old pattern. The New Leadership Education and Training demonstrates a novelty that fulfilled the requirement as an innovation. The innovation was actualized as planned and systematically towards greater outcome, greater benefit, greater impact, cost effective, lesser risk, lesser resources, and greater performance. The novelty in the New Leadership Education and Training compared to the Old Leadership Education and Training is illustrated in Table 3 below:

Table 3 Novelty of New Leadership Education and Training Model

\begin{tabular}{lll}
\hline Dimension & $\begin{array}{l}\text { Old Leadership } \\
\text { Education and Training }\end{array}$ & $\begin{array}{l}\text { New Leadership } \\
\text { Education and Training }\end{array}$ \\
\hline Policy & $\begin{array}{l}\text { Output-oriented participant } \\
\text { competency }\end{array}$ & $\begin{array}{l}\text { Outcome-, integrity-, innovation- } \\
\text { and collaboration-oriented networks }\end{array}$ \\
\hline Paradigm & Administration & Public service \\
\hline Approach model & $\begin{array}{l}\text { State centred (by State } \\
\text { Administrative Agency, }\end{array}$ & $\begin{array}{l}\text { A combination between state } \\
\text { centred, pluralistic, and } \\
\text { transnational (intermestic) approach } \\
\text { models }\end{array}$ \\
\hline Provision & $\begin{array}{l}\text { AN). Domestic approach } \\
\text { model }\end{array}$ & $\begin{array}{l}\text { Off-campus education and training } \\
\text { available }\end{array}$ \\
\hline Learning & Off-campus education and & Constructivistic - experience based \\
& training unavailable & learning \\
\hline Change project & Behaviouristic, cognitivistic, \\
competence-based learning & Available \\
\hline Coach \& Mentor & Unavailable & Available \\
\hline Passing output & Unavailable & Less than 100\% \\
\hline Networks concept & 100\% & Available \\
\hline $\begin{array}{l}\text { Intensity of } \\
\text { collaboration between } \\
\text { institutions }\end{array}$ & Unavailable & High \\
\hline
\end{tabular}

Constructivistic learning model applied to the New Leadership Education and Training had been adequate. However, the implementation had not been effective as expected. The problem lied in the leadership substance as taught and trained by the education and training program. Towards the $21^{\text {st }}$ century, the leadership model contains new leadership values to answer the current threats and questions.

\section{CONCLUSION AND RECOMMENDATION}

Based on the findings, it can be concluded that:

a) The leadership of the Semarang Mayor related to disaster and city resilience had been effective but yet unable to improve the effectiveness of the state internal bureaucracy due to structural conflict.

b) The local leadership model that could be proposed for developing a resilient city towards the Semarang RC was a partnership-based congruent model, in which public and private sectors co-operate to implement a city resilience forum. 
PLANNING MALAYSIA:

Journal of the Malaysia Institute of Planners (2017)

c) The ideal learning model applied to the Leadership Education and Training was constructivist with an intuitive approach.

Recommendations to be proposed according to the findings of this study were as follows:

a) As a regulator, the municipal government of Semarang must re-evaluate its policies and programs for aiming targets in line with the actual needs. The municipal government must also perform periodical monitoring and evaluation over the policies and programs transparently for their sustainability.

b) As a facilitator, the municipal government of Semarang has to make effort to improve community awareness of the importance of the city resilience by socializing and updating issues, programs, achievements by means of official website, printed and electronic mass media, and social media networks.

c) There is a need for integration and co-ordination between formal organization (the government) and informal organizations, either internally (inside the administrative border of Semarang Municipality) or externally (areas nearby the city), in order to manifest local leadership for the successfully implemented city resilience program and policy.

d) Citizens of Semarang are expected to participate in activities dealing with decision-making, in particular those related to the city resilience, either in the planning, implementation, monitoring, or evaluation processes.

e) There is a need for mobilization and recognition of actual roles played by private sector by a co-ordination in planning and utilizing the CSR programs in integrated, transparent, and sustainable manners.

\section{ACKNOWLEDGMENT}

The author is indebted to all individuals with their own contribution towards the completion of this paper: Hendrar Prihadi, Herru Setiadhi, Bambang Haryono, Bobi Setiawan, Sigit Sumarhaen Yanto, Nugroho in Saputra, Wiwandari Handayani, Happy Santosa, Johan Silas, Prihadi, Jawoto, Pur, Joko, Lutfi and Mega. Special thanks go to Toton, Myrna, Arga, Mita, Nizar and Yaniz.

\section{REFERENCES}

Bisrie M. B.F., Salim A. W., \& Suroso D. S. A. (2011). Entry points. 2nd International Conference on "Cities at Risk", Taiwan, 11 - 13 April 2011.

Budiati, L. (2015). Diklat kepemimpinan pola baru dalam prespektif inovasi dan pembelajaran konstruktivistik. Jurnal Pembangunan Wilayah \& Kota, 11(2), 211-221.

Etzioni A., \& Gross E. (1985). Organizations in society. Englewood Cliff: Prentice-Hall Handayani W. (2015). Strategi Ketahanan Kota Semarang: Menuju Keselamatan Pangan, Air, dan Energi Melalui Adaptasi Perubahan Iklim. 100 Resilient Cities. 
Lilin Budiati

Local Leadership Model Towards a Resilient City in Semarang Municipality

Retrieved on October 17, 2016 from https://drive.google.com/file/d/ 0BxfH4L8MDpwhX1pGeE42bGF5c00/view.

Hersey P., \& Blanchard K. H. (1998). Management and organizational behavior. Englewood Cliff: Prentice-Hall.

Kartono K. (2003). Pemimpin dan kepemimpinan. Jakarta: PT Raja Grafindo.

Municipal Government of Semarang (2016). Laporan Kelompok Kerja (Pokja) Kapasitas Tim RC Semarang.

Nadler D. A., \& Tushman M. L. (1997). Competing by design: the power of organization architecture. New York: Oxford University Press.

Peraturan Kepala BNPB (2008). Pembentukan Badan Penanggulangan Bencana Daerah $(B P B D)$ No. 3.

Peraturan Menteri Dalam Negeri (2008). Pedoman organisasi dan tata kerja Badan Penanggulangan Bencana Daerah (BPBD) No. 46.

Remenyi D., Williams B., Money A., \& Swartz E. (1998). Doing research in business and management. London: Sage Production.

Williams G., \& Cudjoe-Braithwaite J. (2012). Electronic goal management. a case study in the water and sewerage authority. Retrieved on October 18, 2016 from http://unpan1.un.org/intradoc/groups/public/documents/undpadm/unpan049780 .pdf. 